\title{
A Study to Assess the Quality of Life and Its Clinical and Psychological Determinants among Cancer Patients Receiving Chemotherapy at Selected Hospitals of Bagalkot
}

\author{
Vishwanath Ganiger*, Shilpa N. Kugali**, Deelip. S. Natekar*** \\ *M.Sc. (Nursing), Department of Community Health Nursing, BVV Sangha's Sajjalashree Institute of Nursing \\ Sciences, Navanagar, Bagalkot - 587102 \\ **Associate Professor, Department of Community Health Nursing, B.V.V. Sangha's Sajjalashree Institute of \\ Nursing Sciences, Navanagar, Bagalkot - 587102 \\ ***Principal, B.V.V. Sangha's Sajjalashree Institute of Nursing Sciences, Navanagar, Bagalkot - 587102
}

Corresponding Author: Deelip. S. Natekar

DOI: https://doi.org/10.52403/ijshr.20220131

\begin{abstract}
The global cancer burden is estimated to have risen to 18.1 million new cases and 9.6 million deaths in 2018. One in 5 men and one in 6 women worldwide develop cancer during their lifetime, and one in 8 men and one in 11 women die from the disease. Worldwide, the total number of people who are alive within 5 years of a cancer diagnosis, called the 5-year prevalence, is estimated to be 43.8 million. The increasing cancer burden is due to several factors, including population growth and ageing as well as the changing prevalence of certain causes of cancer linked to social and economic development.
\end{abstract}

Methods: The research approach adopted in this present study is quantitative non experimental approach and the research design Descriptive Cross sectional Explorative design. 50 samples of cancer patients who are receiving chemotherapy at selected hospitals of Bagalkot, were selected by disproportionate stratified random sampling technique. A structured questionnaire was developed to collect the demographic information, a structured questionnaire was developed to assess the level of quality of life, Pain, Nausea and Vomiting, Stress and Anxiety. The level of pain will be assessed with the use of a numeric pain scale. The nausea and vomiting will be measured by Standardised MASCC Antiemesis Tool (MAT), Stress will be measured by Cohen's perceived stress scale. The degree of anxiety will be measured by Zung self-rating anxiety scale (SAS). The data collected and analyzed using descriptive and inferential statistics.

Results: The level of knowledge regarding cancer among cancer patients reveals that, Most of patients $(34 \%)$ had moderate QOL knowledge, $22 \%$ of them had high QOL knowledge, $40 \%$ of them had power QOL knowledge. The level of knowledge regarding cancer among cancer patients reveals that, Most of patients (44\%) had worst possible pain, $40 \%$ of them had moderate pain, $16 \%$ of them had mild pain, $0 \%$ them had no pain. The level of nausea and vomiting of cancer among cancer patients reveals that, Most of patients (64\%) had high nausea and vomiting, 26\% of them had moderate nausea and vomiting, 6\% had low nausea and vomiting, $4 \%$ of them had minimal nausea and vomiting. The level of stress level among cancer patients reveals that, Most of patients (58\%) had high stress level, $28 \%$ of them had moderate stress level, $14 \%$ of them had low stress level. The level of anxiety regarding cancer among cancer patients reveals that, Most of patients (40\%) had mild to moderate anxiety level, $30 \%$ of them had moderate to severe anxiety level, $24 \%$ of them had extreme anxiety level, $6 \%$ of them had normal range level. Assessment of the level of Quality of life of the cancer patients reveals that majority The level of knowledge regarding cancer among cancer patients reveals that, Most 
Vishwanath Ganiger et.al. A study to assess the quality of life and its clinical and psychological determinants among cancer patients receiving chemotherapy at selected hospitals of Bagalkot.

of patients (38\%) had moderate QOL knowledge, $22 \%$ of them had high QOL knowledge, $40 \%$ of them had power QOL knowledge. The level of quality of life of cancer among cancer patients reveals that, Most of patients (44\%) had worst possible pain, $40 \%$ of them had moderate pain, $16 \%$ of them had mild pain, $0 \%$ them had no pain. The level of quality of life of cancer among cancer patients reveals that, Most of patients $(64 \%)$ had high nausea and vomiting, $26 \%$ of them had moderate nausea and vomiting, 6\% had low nausea and vomiting, $4 \%$ of them had minimal nausea and vomiting. The level of quality of life of cancer among cancer patients reveals that, Most of patients $(58 \%)$ had high stress level, $28 \%$ of them had moderate stress level, $14 \%$ of them had low stress level. The level of knowledge regarding cancer among cancer patients reveals that, Most of patients (40\%) had mild to moderate anxiety level, $30 \%$ of them had moderate to severe anxiety level, $24 \%$ of them had extreme anxiety level, $6 \%$ of them had normal range level. The mean, SD, and mean percentage of knowledge scores of cancer patients reveals that, The total mean percentage of Physical well being was $20.6 \%$, mean 103.71 and SD 38.25. The total mean percentage of social well being was $21.2 \%$, mean 106.28 and SD 33.50. The total mean percentage of emotional well being was $22 \%$, mean 110.66 and SD 34.45. The total mean percentage of functional well being was $22.2 \%$, mean 111.28 and SD 37.05. The mean, SD, and mean percentage of knowledge scores of cancer patients reveals that, The total mean percentage of numeric pain scale was $30.2 \%$, mean 151 and SD 42.05. The mean, SD, and mean percentage of knowledge scores of cancer patients reveals that, The total mean percentage of MASCC antiemesis scale was $91.1 \%$, mean 45.5 and SD 8.33. The mean, SD, and mean percentage of knowledge scores of cancer patients reveals that, The total mean percentage of Perceived stress scale was $11.2 \%$, mean 56 and SD 14.75. The mean, SD, and mean percentage of knowledge scores of cancer patients reveals that, The total mean percentage of Zung-self rating scale was 20.4\%, mean 102.78 and SD 44.12.

Conclusion: Finding shows that, there is significant difference in knowledge especially cancer patient who are fighting with cancer cells in their body showing maximum symptoms related to adverse effects of treatment.
Keywords: Quality of life, Clinical and psychological determinants, Cancer Patients, Pain, Stress, Nausea and vomiting, Anxiety.

\section{INTRODUCTION}

According to the World Health Organization (WHO), quality of life (QoL) is defined as individual perception of life, values, objectives, standards, and interests in the framework of culture. QoL is increasingly being used as a primary outcome measure in studies to evaluate the effectiveness of treatment. Patients generally instead of measuring lipoprotein level, blood pressure, and the electrocardiogram, make decisions about their health care by means of QoL which estimates the effects on outcomes important to themselves. ${ }^{[1]}$ A recent report published by National Cancer Registry Programme (NCRP) estimates that the number of cancer cases is likely to increase from 13.9 lakh in 2020 to 15.7 lakh by 2025 , an increase of nearly $20 \%$. However, the one good thing is that at least one-third of common cancers are preventable. India's cancer burden could increase from 1.39 million to 1.57 million by 2025 , according to the recently published report of National Cancer Registry Programme 2020. ${ }^{[2]}$ The National Cancer Registry Programme (NCRP) Report 2020 has estimated that based on current trends there will be 13.9 lakh cancer cases across the country by the end of 2020, the Indian Council of Medical Research said on Friday. According to the report, the number of cancer cases is likely to increase to 15.7 lakh by 2025."The National Cancer Registry Programme (NCRP) Report 2020, released by ICMR and National Centre for Disease Informatics and Research, Bengaluru, estimates that based on current trends, there will be 13.9 lakh cancer cases by the end of 2020 which is likely to increase to 15.7 lakhs by 2025," ICMR tweeted. [3]

Cancer affects a person's quality of life (QOL) in almost every domain. The impairment in the QOL starts from the diagnosis of cancer and continues till the treatment. Chemotherapy is one of the most 
common treatment modalities that patients receive to combat cancer. Among $65 \%$ of the cancer population, $25 \%$ patients receive chemotherapy as the first line of treatment. ${ }^{[4]}$ Chemotherapy is used to treat cancers by killing the rapidly growing abnormal cells and is believed to lower the recurrence of cancer and increase the survival rate of patients. ${ }^{[5]}$

Apart from therapeutic effects of chemotherapy, there are several commonly reported side effects experienced by patients during and after chemotherapy cycles are nausea/vomiting, thrombocytopenia, mouth ulcers, and fatigue. ${ }^{[6-10]}$

Chemotherapy treatment produces an enormous physical, psychological, and emotional trauma among cancer patients, influencing their quality of life.

Cancer patients experience many symptoms that affect their quality of life. There is a need to develop interventions for effective management of symptoms that will empower the patients to have a greater sense of control over their illness and treatment and to improve the quality of life. ${ }^{[11]}$

\section{METHODOLOGY}

Research design: The term research design refers to the plan of a scientific investigation. Research design help the researcher in selection of subjects, identification of variables, their manipulation and control, observation to be made and types of statistical analysis to interpret the data. In the present study Descriptive Cross sectional Explorative design has been adopted.

Variables of the study: Variable is a content that has measurable changing attributes. Variables are qualities, properties, or characteristics of persons, things, or situation that change or vary.

Three types of variables were identified in this study. They are as fallows.

\section{- Independent Variable: Quality Of Life}

Dependent Variable: Clinical Determinants- Pain, Nausea and Vomiting, Psychological Determinants- Stress and Anxiety.
Selected Socio demographic Variables: Age, Gender, Duration, Type of cancer, Education, Occupation, Marital status, Religion, Number of members in the family, Type of treatment, Numbers of treatment of cycle, Side effects of cancer treatment, Have you practiced any relaxation therapies at home? If yes How many times /day /week and what therapy, Source of information of any relaxation therapies.

Setting of the study: The setting is where the population or the portion of it being studied is located and where the study is carried out. The present study was conducted at Ashirvad Hospital Bagalkot for Pilot study and Kerudi cancer Hospital Bagalkot for main study.

Population: A population is complete set of persons or subjects that passes common characteristics that is of interest to the researcher.

Target Population: In the present study target population include all cancer patients receiving chemotherapy in Hospitals of Bagalkot district.

Accessible Population: In the present study accessible population include cancer patients receiving chemotherapy at Ashirvad hospital and Kerudi cancer hospital of Bagalkot.

Sample: A sample is a subset of population from which the actual data is collected. The samples of study are Cancer patients in Receiving chemotherapy at Ashirvad hospital and Kerudi hospital Bagalkot and those who fulfill the sampling criteria. Sample size is calculated by using power analysis after pilot study. The result of sample size estimation is 50 cancer patients.

Sampling Technique: Sampling technique is the process of selecting a portion of the population to obtain data regarding a problem.

In the present study - Simple Random Sampling Technique is used for selection of samples for the study. 
Criteria for selection of sample: The sampling frame structured by the researcher includes the following criteria.

Inclusion criteria for sampling: The study includes cancer patients, who are, all age group of cancer patients, Patients who were admitted with cancer and came for receiving Chemotherapy in for hospital, Patients who are staying in hospital at least 1 to 2days, Able to understand Kannada or English, Available at the time of data collection, Willing to participate in the study.

Exclusion criteria for sampling: The study excludes cancer patients, who are, severely ill and unable to provide data, Patients with sensory organ impairment, Unable to cooperate throughout the period of study.

\section{RESULT}

Presentation of Data: To begin with, data was entered in a master sheet for tabulation and statistical processing. The findings were presented under the following headings.

Part I: Description of the sociodemographic characteristics of sample.

Part II: Assessment of extent of level related to quality of life and its clinical and psychological determinants among cancer patients receiving chemotherapy.

Part III: Assessment of differences between level of quality of life and its clinical and psychological determinants among cancer patients receiving chemotherapy.

Part IV: Association of the socio demographic variables among cancer patients with their quality of life scores.

Part II: Assessment of extent of level related to quality of life and its clinical and psychological determinants among cancer patients receiving chemotherapy.

\section{A) FACT-G Scale}

\begin{tabular}{|l|l|l|l|}
\hline $\begin{array}{l}\text { Level } \\
\text { Knowledge }\end{array}$ & $\begin{array}{l}\text { Range of } \\
\text { score }\end{array}$ & Frequency & Percentage \\
\hline Lower QOL & $0-44$ & 20 & $40 \%$ \\
\hline Moderate QOL & $45-90$ & 19 & $38 \%$ \\
\hline High QOL & $91-135$ & 11 & $22 \%$ \\
\hline
\end{tabular}

B) Numeric pain scale

\begin{tabular}{|l|l|l|l|}
\hline Level of pain & $\begin{array}{l}\text { Range of } \\
\text { score }\end{array}$ & Frequency & Percentage \\
\hline No pain & 0 & 0 & $0 \%$ \\
\hline Mild pain & $1-3$ & 8 & $16 \%$ \\
\hline Moderate pain & $4-6$ & 20 & $40 \%$ \\
\hline $\begin{array}{l}\text { Worst possible } \\
\text { pain }\end{array}$ & $7-10$ & 22 & $44 \%$ \\
\hline
\end{tabular}

\section{C) Nausea and Vomiting (MAT) scale} N-50

\begin{tabular}{|l|l|l|l|}
\hline $\begin{array}{l}\text { Level of nausea of } \\
\text { vomiting }\end{array}$ & $\begin{array}{l}\text { Range of } \\
\text { score }\end{array}$ & Frequency & Percentage \\
\hline $\begin{array}{l}\text { High nausea \& } \\
\text { vomiting }\end{array}$ & $8-10$ & 32 & $64 \%$ \\
\hline $\begin{array}{l}\text { Moderate nausea \& } \\
\text { vomiting }\end{array}$ & $5-7$ & 13 & $26 \%$ \\
\hline $\begin{array}{l}\text { Low nausea \& } \\
\text { vomiting }\end{array}$ & $3-4$ & 3 & $6 \%$ \\
\hline $\begin{array}{l}\text { Minimal nausea \& } \\
\text { vomiting }\end{array}$ & $0-2$ & 2 & $4 \%$ \\
\hline
\end{tabular}

D) Stress (Cohen's perceived stress scale) N-50

\begin{tabular}{|l|l|l|l|}
\hline Level of stress & Range of score & Frequency & Percentage \\
\hline Low stress & $0-18$ & 7 & $14 \%$ \\
\hline Moderate stress & $19-37$ & 14 & $28 \%$ \\
\hline High stress & $38-56$ & 29 & $58 \%$ \\
\hline
\end{tabular}

E) Anxiety (Zung Self rating scale) N-50

\begin{tabular}{|l|l|l|l|}
\hline $\begin{array}{l}\text { Level of anxiety } \\
\text { level }\end{array}$ & $\begin{array}{l}\text { Range of } \\
\text { score }\end{array}$ & Frequency & Percentage \\
\hline Normal range & $20-44$ & 3 & $6 \%$ \\
\hline $\begin{array}{l}\text { Mild to Moderate } \\
\text { anxiety Level }\end{array}$ & $45-59$ & 20 & $40 \%$ \\
\hline $\begin{array}{l}\text { Moderate to Severe } \\
\text { anxiety level }\end{array}$ & $60-74$ & 15 & $30 \%$ \\
\hline Extreme anxiety level & Above 75 & 12 & $24 \%$ \\
\hline
\end{tabular}

Part III: Assessment of differences between level of quality of life and its clinical and psychological determinants among cancer patients receiving chemotherapy.

Mean, Standard deviation of Quality of life Scores

\section{A) FACT_G scale N-50}

\begin{tabular}{|l|l|l|l|l|}
\hline & $\begin{array}{l}\text { Max } \\
\text { score }\end{array}$ & Mean & SD & Mean\% \\
\hline Physical well being & 35 & 103.71 & 38.25 & $20.6 \%$ \\
\hline Social well being & 35 & 106.28 & 33.50 & $21.2 \%$ \\
\hline Emotional well being & 30 & 110.66 & 34.45 & $22 \%$ \\
\hline $\begin{array}{l}\text { Functional well } \\
\text { being }\end{array}$ & 35 & 111.28 & 37.05 & $22.2 \%$ \\
\hline
\end{tabular}

B) Numeric pain scale
\begin{tabular}{|l|l|l|l|l|}
\hline & Max score & Mean & SD & \multicolumn{1}{c|}{ M-50an $\%$} \\
\hline Numeric pain scale & 10 & 151 & 42.05 & $30.2 \%$ \\
\hline
\end{tabular}

\section{C) MASCC Antiemesis scale $\quad \mathbf{N}-50$}

\begin{tabular}{|ll|l|l|l|l|}
\hline & $\begin{array}{l}\text { Max } \\
\text { score }\end{array}$ & Mean & SD & Mean\% \\
\hline $\begin{array}{l}\text { MASCC } \\
\text { scale }\end{array}$ & Antiemesis & 10 & 45.5 & 8.33 & $91.1 \%$ \\
\hline
\end{tabular}


Vishwanath Ganiger et.al. A study to assess the quality of life and its clinical and psychological determinants among cancer patients receiving chemotherapy at selected hospitals of Bagalkot.

D) Cohn's perceived stress scale $\mathbf{N}-50$

\begin{tabular}{|l|l|l|l|l|}
\hline & Max score & Mean & SD & Mean\% \\
\hline Perceived stress scale & 56 & 56 & 14.75 & $11.2 \%$ \\
\hline \multicolumn{5}{|l|}{} \\
\begin{tabular}{|l|l|l|l|} 
E) Zung-self rating scale \\
\hline
\end{tabular} & $\begin{array}{l}\text { Max } \\
\text { score }\end{array}$ & Mean & SD & Mean\% \\
\hline $\begin{array}{l}\text { Zung-self rating } \\
\text { scale }\end{array}$ & 80 & 102.78 & 44.12 & $20.4 \%$ \\
\hline
\end{tabular}

PART -IV; Association of the socio demographic variables among cancer patients with their quality of life scores.

To find out the association of quality of life of cancer patients with their socio-demographic variables a research hypothesis was formulated.

A) FACT-G SCALE
\begin{tabular}{|l|l|l|l|}
\hline $\begin{array}{l}\text { Demographic } \\
\text { Variables }\end{array}$ & $\begin{array}{l}\text { Value of Chi- } \\
\text { Square test }\end{array}$ & $\begin{array}{l}\text { P } \\
\text { Value }\end{array}$ & $\begin{array}{l}\text { Level } \\
\text { Significance }\end{array}$ \\
\hline Age & 0.019 & 0.88 & NS \\
\hline Gender & 0.04 & 0.94 & NS \\
\hline Education & 0.005 & 0.945 & NS \\
\hline Type of family & 1.203 & 0.27 & NS \\
\hline Religion & 2.078 & 0.14 & NS \\
\hline $\begin{array}{l}\text { Number of family } \\
\text { members }\end{array}$ & 0.558 & 0.45 & NS \\
\hline Marital status & 0.263 & 0.60 & NS \\
\hline Family income & 1.202 & 0.27 & NS \\
\hline Dietary pattern & 0.231 & 0.63 & NS \\
\hline Present occupation & 0.325 & 0.56 & NS \\
\hline
\end{tabular}

\section{B) NUMERIC PAIN SCALE}

\begin{tabular}{|l|l|l|l|}
\hline $\begin{array}{l}\text { Demographic } \\
\text { Variables }\end{array}$ & $\begin{array}{l}\text { Value of Chi- } \\
\text { Square test }\end{array}$ & $\begin{array}{l}\mathbf{P} \\
\text { Value }\end{array}$ & $\begin{array}{l}\text { Level of } \\
\text { Significance }\end{array}$ \\
\hline Age & 0.253 & 0.61 & NS \\
\hline Gender & 3.687 & 0.054 & Significant \\
\hline Education & 4.023 & 0.044 & Significant \\
\hline Type of family & 0.081 & 0.77 & NS \\
\hline Religion & 2.585 & 0.107 & NS \\
\hline $\begin{array}{l}\text { Number of family } \\
\text { members }\end{array}$ & 0.216 & 0.64 & NS \\
\hline Marital status & 2.131 & 0.14 & NS \\
\hline Family income & 0.905 & 0.34 & NS \\
\hline Dietary pattern & 2.991 & 0.083 & NS \\
\hline Present occupation & 0.344 & 0.55 & $\mathrm{NS}$ \\
\hline
\end{tabular}

\section{C) MASCC ANTIEMESIS SCALE N-50}

\begin{tabular}{|l|l|l|l|}
\hline $\begin{array}{l}\text { Demographic } \\
\text { Variables }\end{array}$ & $\begin{array}{l}\text { Value of Chi- } \\
\text { Square test }\end{array}$ & $\begin{array}{l}\text { P } \\
\text { Value }\end{array}$ & $\begin{array}{l}\text { Level of } \\
\text { Significance }\end{array}$ \\
\hline Age & 0.184 & 0.66 & NS \\
\hline Gender & 1.529 & 0.21 & NS \\
\hline Education & 0.628 & 0.42 & NS \\
\hline Type of family & 1.739 & 0.18 & NS \\
\hline Religion & 1.087 & 0.29 & NS \\
\hline $\begin{array}{l}\text { Number of family } \\
\text { members }\end{array}$ & 0.637 & 0.42 & NS \\
\hline Marital status & 4.741 & 0.029 & S \\
\hline Family income & 2.630 & 0.104 & NS \\
\hline Dietary pattern & 0.002 & 0.96 & NS \\
\hline Present occupation & 0.867 & 0.35 & NS \\
\hline
\end{tabular}

D) PERCIEVED STRESS SCALE N-50

\begin{tabular}{|l|l|l|l|}
\hline $\begin{array}{l}\text { Demographic } \\
\text { Variables }\end{array}$ & $\begin{array}{l}\text { Value of Chi- } \\
\text { Square test }\end{array}$ & $\begin{array}{l}\mathbf{P} \\
\text { Value }\end{array}$ & $\begin{array}{l}\text { Level } \\
\text { Significance }\end{array}$ \\
\hline Age & 0.927 & 0.33 & NS \\
\hline Gender & 0.215 & 0.64 & NS \\
\hline Education & 0.081 & 0.77 & NS \\
\hline Type of family & 1.422 & 0.23 & NS \\
\hline Religion & 0.397 & 0.52 & NS \\
\hline $\begin{array}{l}\text { Number of family } \\
\text { members }\end{array}$ & 3.848 & 0.049 & S \\
\hline Marital status & 0.791 & 0.37 & NS \\
\hline Family income & 0.325 & 0.56 & NS \\
\hline Dietary pattern & 5.966 & 0.014 & S \\
\hline Present occupation & 0.980 & 0.32 & NS \\
\hline
\end{tabular}

E) ZUNG-SELF RATING SCALE; N-50

\begin{tabular}{|l|l|l|l|}
\hline $\begin{array}{l}\text { Demographic } \\
\text { Variables }\end{array}$ & $\begin{array}{l}\text { Value of Chi- } \\
\text { Square test }\end{array}$ & $\begin{array}{l}\mathbf{P} \\
\text { Value }\end{array}$ & $\begin{array}{l}\text { Level of } \\
\text { Significance }\end{array}$ \\
\hline Age & 0.141 & 0.70 & NS \\
\hline Gender & 1.751 & 0.18 & NS \\
\hline Education & 2.538 & 0.11 & NS \\
\hline Type of family & 1.389 & 0.23 & NS \\
\hline Religion & 0.496 & 0.48 & NS \\
\hline $\begin{array}{l}\text { Number of family } \\
\text { members }\end{array}$ & 5.632 & 0.017 & S \\
\hline Marital status & 1.202 & 0.27 & NS \\
\hline Family income & 0.216 & 0.64 & NS \\
\hline Dietary pattern & 0.082 & 0.77 & NS \\
\hline Present occupation & 1.213 & 0.27 & NS \\
\hline
\end{tabular}

\section{CONCLUSION}

This study shows that there is significant difference in knowledge especially cancer patient who are fighting with cancer cells in their body showing maximum symptoms related to adverse effects of treatment. There is a need to develop interventions for effective management of symptoms that are faced by the cancer patients to have control over their illness and to improve the quality of life.

\section{Recommendations}

Based on the findings of the study the fallowing recommendations are made:

1. A similar study can be conducted among cancer patients receiving chemotherapy.

2. Effectiveness of teaching programs to teach family members of cancer patient on basic knowledge on cancer may be tested.

3. Follow- up study can be conducted to evaluate the effectiveness of an information guide sheet.

4. There is need and scope for counseling services to be offered to family members and their cancer patients. 
Acknowledgement: None

\section{Conflict of Interest: None}

\section{Source of Funding: None}

\section{Ethical Approval: Approved}

\section{REFERENCES}

1. Guyatt GH, Feeny DH, Patrick DL. Measuring health-related quality of life. Ann Intern Med. 1993 Apr 15;118(8):622-9. doi: 10.7326/0003-4819-118-8-19930415000009. PMID: 8452328.

2. WHO70.12: Cancer prevention and control in the context of an integrated approach. Global action plan for the prevention and control of NCDs 2013-2020.

3. ETHealthworld.com, India to have 13.9 lakh cancer cases by year-end, 15.7 lakh by 2025: ICMR, October 09, 2020. https://health.economictimes.indiatimes.co $\mathrm{m} /$ news/diagnostics/india-to-have-13-9lakh-cancer-cases-by-year-end-15-7-lakhby-2025-icmr/78572244

4. Milliman. Cancer Patients Receiving Chemotherapy: Opportunities for Better Management. 2010. Available from: https://us.milliman.com/en/insight/res earch/health/cancer-patients-receivingchemotherapy-opportunities-for-bettermanagement/

5. DeVita VT, Chu E. A history of cancer chemotherapy. Cancer Res. 2008;68:864353.

6. Rashid YA, Ghafoor ZA, Masood N, Mehmood T, Awan S, Ansar T, et al. Psychosocial impact of cancer on adult patients. J Pak Med Assoc. 2012;62:905-9.
7. Farrell $C$, Brearley SG, Pilling $M$, Molassiotis A. The impact of chemotherapy-related nausea on patients' nutritional status, psychological distress and quality of life. Support Care Cancer. 2013;21:59-66.

8. Younus J, Vandenberg T, Jawaid M, Jawaid MA. Febrile neutropenia rates with adjuvant docetaxel and cyclophosphamide chemotherapy in early breast cancer: Discrepancy between published reports and community practice-an updated analysis. Curr Oncol. 2012;19:332-4.

9. Dodd MJ, Dibble S, Miaskowski C, Paul S, Cho M, MacPhail L, et al. A comparison of the affective state and quality of life of chemotherapy patients who do and do not develop chemotherapy-induced oral mucositis. J Pain Symptom Manage. 2001; 21:498-505.

10. Karthikeyan G, Jumnani D, Prabhu R, Manoor UK, Supe SS. Prevalence of fatigue among cancer patients receiving various anticancer therapies and its impact on quality of life: A cross-sectional study. Indian J Palliat Care. 2012;18:16575.

11. Nayak MG, George A, Vidyasagar MS, et al. Quality of Life among Cancer Patients. Indian J Palliat Care. 2017;23(4): 445-450. doi:10.4103/IJPC.IJPC_82_17

How to cite this article: Ganiger V, Kugali SN, Natekar DS. A study to assess the quality of life and its clinical and psychological determinants among cancer patients receiving chemotherapy at selected hospitals of Bagalkot. International Journal of Science \& Healthcare Research. 2022; 7(1): 193-198. DOI: https://doi.org/ 10.52403/ijshr.20220131 